\title{
SMALL AGRICULTURAL FARMS IN LATVIA AND BALTIC SEA COUNTRIES AND THEIR POSSIBILITIES
}

Armands Veveris ${ }^{1}$, Dr.oec.; Armands Puzulis ${ }^{2}$, Dr.geogr.

1,2 Institute of Agrarian Resources and Economics, Latvia

\begin{abstract}
The study was conducted with a purpose to find out importance, development and its opportunities of the small agricultural farms in Latvia, taking into account the situation also in other countries of the Baltic Sea. Topicality of the paper is related to a large share of the small agricultural farms in the structure of the agricultural farms, and their very significant impact on the socio-economic situation in the rural areas. The economic activity of the small agricultural farms at the same time in general is low, and their potential (land, workforce, manufacturing resources) is not sufficiently used. Many small farms discontinue their operation, and only a relatively small portion of them become larger.

The paper contains a scientific discussion regarding a socio-economic importance of the small agricultural farms in the rural community, especially in the facilitation of its sustainability. Also it includes results of some surveys conducted in Latvian small farms and analyse of farm structural data. It shows that the small agricultural farms exist also in the EU-15 Member States, and they can operate along with the large farms. The study results show that it is not correct to assess only the economic aspects of these farms separately from the social and environmental aspects. Several niches exist where such farms can successfully operate. These are not the mass products, but rather the products with high value added. For the small farms to be able to create competitive manufacturing, a purposeful investment support suitable for these farms is extremely necessary.
\end{abstract}

Key words: agriculture, small farms, structure, development.

JEL code: 013, Q18

\section{Introduction}

A proportion of the small agricultural farms in Latvia is one of the largest in the EU with a very significant impact on the socio-economic situation in the rural areas, especially on the territories far from the development centres. The economic activity of these agricultural farms in general is, however, low, and their potential (land, workforce, manufacturing resources) are not being sufficiently used. Changes in the structure of the agricultural farms of Latvia take place slowly, and they are mostly related to termination of operation of the small agricultural farms but significantly less to their development. This thematic study is therefore conducted with a purpose to reveal the current situation of the small agricultural farms (hereinafter - the small farms or SF) and their development possibilities in Latvia. The situation of SF in other Baltic Sea countries also is analysed. The hypothesis set for this study is that the operation of the small farms under certain conditions can be successful and sustainable.

The following tasks were therefore established for the study:

- general characteristics of the small farms and their role in ensuring sustainable operation;

- study the structure and development trends of the small farms in Latvia and selected EU Member States;

- assessment of the prospective directions of development of these farms.

The following materials were used in the study: scientific literature, including the study results, various level (international, EU and Latvian) strategic and programmatic documents; Eurostat and Farm accountancy data network (FADN) database data; survey data conducted in Latvian small farms at 2017. Since the farm structural survey is conducted once in 3 years, the latest available data regarding the structure of the farms in the EU Member States is for the year 2013. They, however, sufficiently reveal the trends, therefore may be used in this study. 
Qualitative and quantitative economic research methods: analysis and synthesis; comparative analysis, logically and abstractly constructive methods were used in the study, performing analysis of various scientific publications, laws and regulations, documents, programmes and information sources. Also survey method is used in the study, using results of two surveys where Latvian small farms are surveyed. One of these surveys was carried out by Institute of Agrarian resources and Economics to assess changes in economic data of farms between 2014 and 2016 (340 valid responses in SF sector), and second was carried out by Latvian Rural Advisory and Training Centre to reveal main problems and development possibilities of small farms (134 responses in SF sector). To compare Latvian data with another countries, seven countries around the Baltic sea are chosen (Lithuania, Poland, Germany, Denmark, Sweden, Finland and Estonia).

Novelty of the paper is linking of the context of economic and rural development (sustainability) of the small farms and recommendations which are taking into account both economic and socioenvironmental aspects of small farms. The matters discussed due to limited size of the paper are analysed to the extent permitted by the size of the publication; only the main indications are therefore discussed in the paper.

The structure of the farms is being analysed, using division of the farms based on their economic size, where the criterion applied is a standard output (SO) used in the database of the Eurostat EU Member State surveys on the structure of agricultural farms. Taking into account the purpose of the paper and the actual structure of the farms in Latvia, the farms with SO value up to EUR 25.000 are considered as small for the purpose of this study.

\section{Research results and discussion}

\section{Small farms - different functions}

A role of the small farms (SF) in the agricultural and rural development contexts has not been fully assessed. The understanding of effectiveness and produce value dominating for decades in the economy did not take into account an impact of sustainability of the rural activity and multifunctionality. Agricultural manufacturing - business - was separated from the cultural context of the rural development, place and communities. The current research and political approaches allow assuming that the role of the SF changes (What is ..., 2011; Davidova \& Thomson, 2013; De Castro et al., 2014 etc.)

Quantitative assessment methods have not yet been designed, unified and broadly accepted to precisely establish a contribution of the SF in creation of public benefit, provision of environmental services and rural development. A new definition for the small farms which would incorporate not only the regulatory approach but also the components of public benefit is currently beings searched for (Gioia, 2017).

Studies and political documents accept the decisive SF role in the context of further rural development (Kern, 2015; Agricultural and Rural Convention, 2010; ESPON \& MCRIT, 2014; FAO, 2014; Ishii-Eiteman, 2009). The main contexts in which the role of SF is being assessed are concepts of sustainability and multi-functionality (Meike, 2017; Tisenkopfs et al, 2015; OECD, 2015; Ambrosio-Albala, M., Bastiaensen, J, 2010; Molders, 2014; Novikova, 2014), which are manifesting as a reduction of poverty and facilitation of employment, creation of attractive rural landscape, as well as density of rural population and development of communities/places (European Parliament, 2013; OECD, 2017). 
Sustainable rural economic activity includes a satisfaction of need for food, raw materials and fuel, by improving quality of environment and resource base, ensuring economic viability of agriculture, life quality of the rural population (Toward..., 2010), which are the most important points of the road map of agriculture in the 21st century.

The dominating philosophy in the world is the industrial one, where agriculture is just another type of business, and the opposite to it - the agrarian philosophy (multi-functional) where the agriculture has social functions and has perceived as a part of the rural community (Thompson, 2010). This is reflected in various policies -the State-supported agriculture or the protectionism approach; the agriculture based on competition following the market liberation, and the EU dominating multi-functional agriculture combing the manufacturing of tradable goods and creation of non-tradable goods. The EU CAP is characterized by conglomerate of various agricultural understandings, which makes it more difficult to implement the policy (Molders, 2014).

Sustainability may be achieved by various forms of farming, but the studies recognize that small farms (compared to the large farms) are more beneficial for reaching the social goals of the community (Meike, 2017). It is determined by both the politics, dominating farming forms and also by the knowledge. A significant factor stimulating change of attitude toward traditional and environmentally-friendly manufacturing methods is a change of the buyers' habits where the ethical side of the manufacturing becomes important (Pollan, 2006).

SF play own different role as a part of rural development in contexts of multi-functionality, externalities, local community preserving uniqueness and potential of place- based innovate development.This part includes: text, tables, figures, formulae with references, data source references, evaluation of validity for calculations. This part may be divided in balanced sub-parts.

\section{Farm structure and tendencies}

Taking into consideration heterogeneity of the agricultural systems, historical heritage, as well as demographic situation and geographic conditions in various countries, idea of a small farm is different. It is affected by the criteria selected for the definition, as well as the goals of various institutions forming the definition, assigning to it a political meaning. The small farmers are not homogeneous; they have different experience and interests, as they contain the farmers well integrated in the market, as well as the poor farmers (Davidova \& Thomson, 2014; Gioia, 2017).

Talking about the small farms, various terms are used, for example, family farm, agroecological farm, natural farm and agricultural farm. Each of these definitions places an emphasis on various aspects of this agricultural system, namely, physical (area) or economic value (SO) - small farm; its main source of workforce - family farm; - main manufacturing method - traditional, organic or agro-ecological; involvement degree in the market - self-consumption, partially natural or involvement in the market (manufacturing of goods) (Gioia, 2017).

A total of 10.8 million farms are recorded in the EU-27 (not including Croatia). A number of these farms relatively rapidly reduced in the entire EU: since 2005 the reduction speed is by $3.7 \%$ per year. Reduction of the farms in Latvia (by $5.5 \%$ per year) is more rapid than in average in the EU. The structure of the farm size in various member states is significantly different (Figure 1 ). Latvia and Lithuania have the largest share of small farms among Baltic Sea countries. Among all EU Member States, Latvia has the fourth largest proportion of such farms (83\%). 


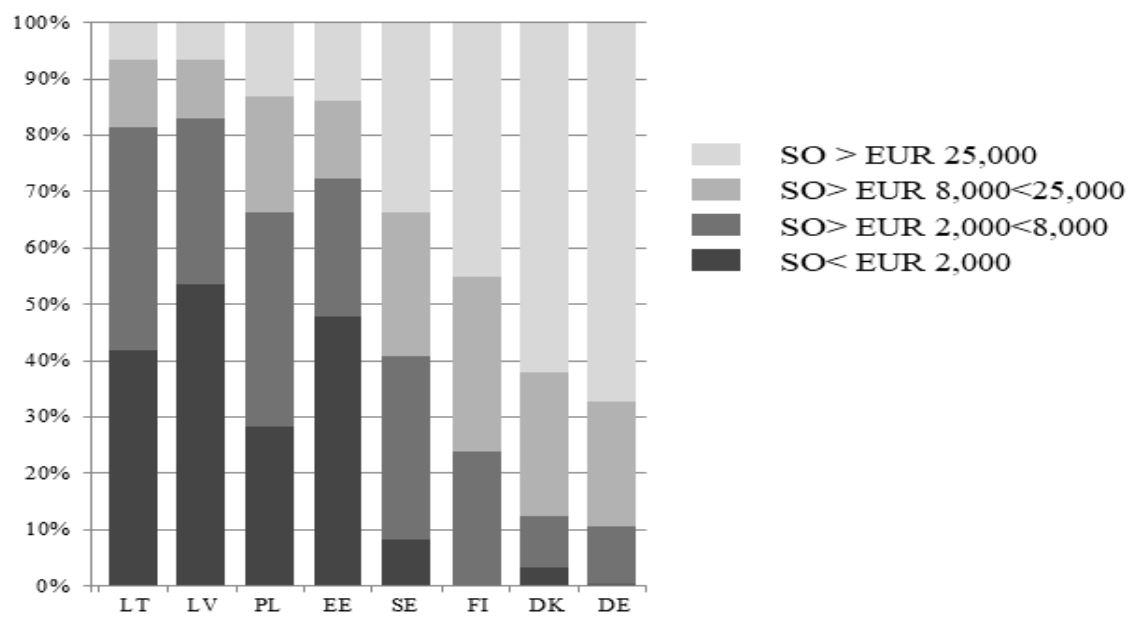

Source: author's calculations based on Eurostat data

Fig. 1. Distribution of farms in the standard output (SO) groups in the selected EU Member States in 2013 ( \% of total)

Approximately one third of the Member States in general has a balanced structure of farms - a large proportion in them is formed by the large, medium and small farms, but it has an insignificant number of very small farms (less than 2 thou EUR of SO). Among Baltic Sea countries, these are Sweden and Finland. From the point of view of the well-balanced development, such structure could be considered as optimum one, as it includes both highly productive farms producing goods for the market, and also the lifestyle farms also manufacturing and earning income even though in a smaller amount. The farms where the production is insignificant or does not take place at all almost do not exist in these countries.

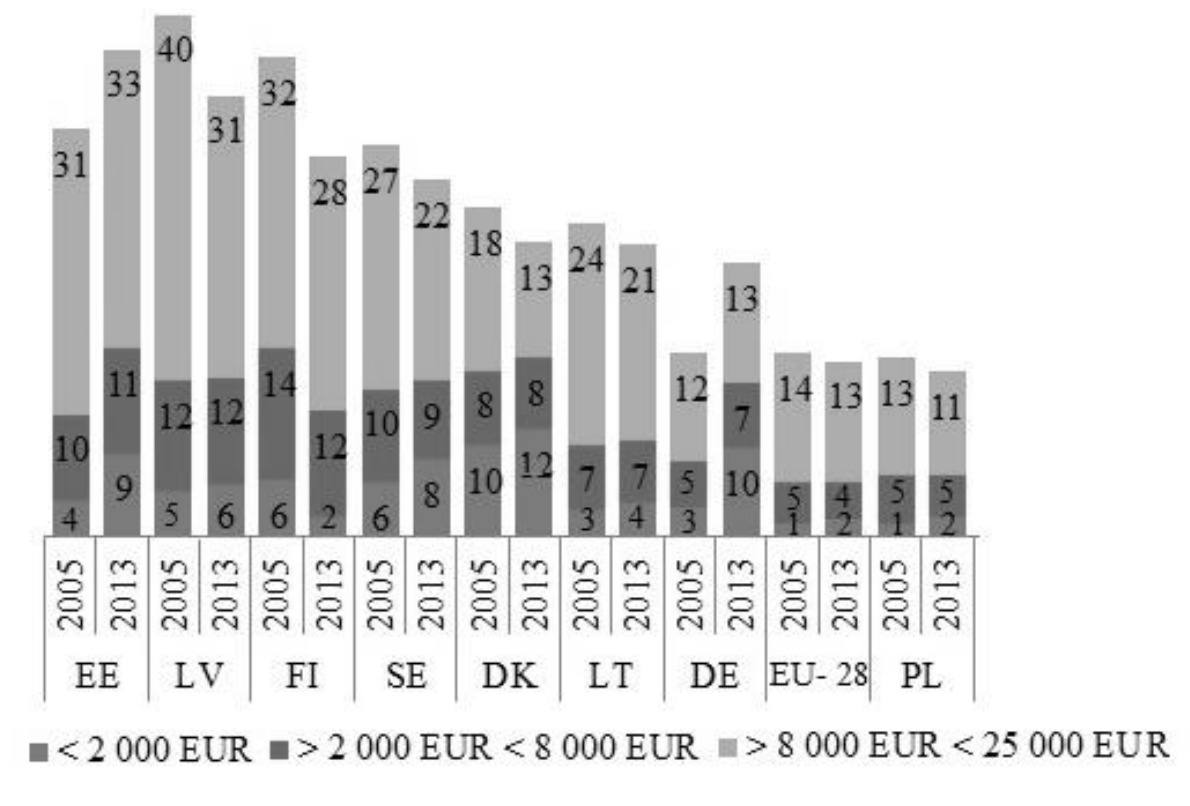

Source: author's calculations based on Eurostat data

Fig. 2. Average UAA in SF groups in Latvia and other Baltic Sea States, ha

The economically large farms not always mean that they are large in area. Average Usable Agricultural Areas (UAA) in each of the viewed farm size groups in Latvia and other EU Member States are summarized in Figure 2. The figure shows that the land areas managed by SF in Latvia are among the largest in the EU Member States. In the group of Latvian farms with SO less than 2 thou EUR, they in average manage 6 ha of UAA, which is the fourth largest indicator among the 
analysed EU Member States. The largest average UAA area is in Denmark, Germany, Estonia and Sweden. In the group of farms with SO between 2 and 8 thou EUR, they in average manage 12 ha of UAA, which is a shared highest indicator with Finland. In all other countries, the relevant areas are smaller. The farms with SO between 8 and 25 thou EUR in Latvia, on the other hand, have the second largest average UAA area after Estonia ( $31 \mathrm{ha}$ ). Average UAA area per one farm affects the potential development opportunities and directions.

SF plays the greatest role in the employment context (Figure 3 ). In this sense, countries expressly divide into two groups - one contains the majority of the new member states, where the proportion of these farms in the agricultural employment is above $70 \%$ in terms of Annual Work Units (AWU). It includes also Latvia with $76 \%$ which is similar to a range of other EU countries (among Baltic Sea countries these are Lithuania and Poland).

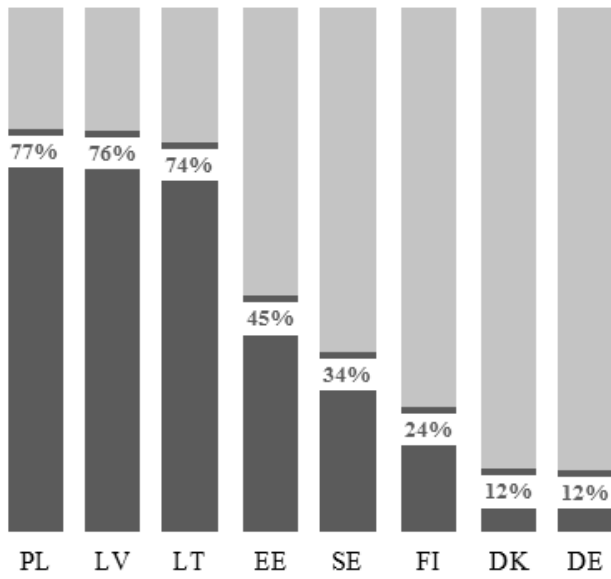

SO $>$ EUR 25,000

SO $<$ EUR 25,000

Source: author's calculations based on Eurostat data

Fig. 3. Share of the employment in small farms (SO < EUR 25.000) in the total agricultural employment in the selected countries (in AWU, 2013)

The general description of the respondent farms obtained from the survey data is as follows: the agricultural farms are maintained because the operation in them is either a lifestyle or the main source of income. Maintaining or increase of the manufacturing volume is planned within the next three years. The implementation of these plans is mostly limited by uncertainties about future in general, as well as lack of the manufacturing and financial resources.

Analysis of the survey results allows distinguishing a range of priorities to become a growing agricultural farm in the respondents' opinion: the payments for the existing area must be maintained, long-term investments must be supported, funds must be granted for acquisition, expansion of land, tax discounts and loans must be granted.

Even though current support to the small agricultural farms, especially in terms of investments, is considered as insufficient (Veveris \& Sapolaite, 2017), the EU policy documents, however, increasingly appreciate importance of the small agricultural farms and express a need to provide a special support to these farms. The Resolution of the European Parliament 2013/2096 (INI) regarding the future of small agricultural farms adopted at the beginning of 2014 is the first document of such importance attesting to directing of the support policy toward facilitation of solutions and development models appropriate for the needs of small and family agricultural farms. It invites the Member States and the European Commission to take appropriate measures in the scope of the new Common Agricultural Policy (2014-2020), as well as prepare the guidelines for the period after 2020, by additionally attracting also other EU policy directions to resolving the 
problems of the small agricultural farms, considering also additional State support. Attention is paid also to the fact that an effective way needs to be found to ensure support also to the small manufacturers of agricultural products, the operation and the products manufactured of what are not related to the title to the agricultural land and/or the use of this land (European Parliament, 2013).

\section{Prospective directions of development}

The results of the performed study show that even though the small farms in their operation face many difficulties, and their number reduces, their importance is still significantly great. Moreover, a contribution of the small farms in maintaining environmentally-friendly, local community-oriented manufacturing and preserving of local traditions on the EU scale is being increasingly appreciated. It allows concluding that the small and large farms are not interchangeable - they to a great extent have their own different niche. Well-balanced structure of farms where the farms of various size, specialization and market orientation are operating may be rated as one of the preconditions for the full-fledged rural development.

SF output, as well as created value added per one person employed in Latvia is one of the lowest in the entire EU (according to FADN data). It means that these farms have an opportunity to increase income, not only becoming larger in terms of manufacturing volume, but also by operating in the existing volume, but by increasing economic activity.

The analysis performed during the preparation of the paper allows concluding that the main reason for the insignificant income of the small farms in Latvia is the low value of the obtained output. It means that the following principal directions are necessary to increase income:

- to produce more in physical sense;

- to produce with higher value added;

- to reduce use of resources' per produced unit.

All these directions have a significant potential in the conditions of Latvia. This is evidenced by the survey results regarding the provisional impact of the Latvian Rural Development Programme 2014-2020. It shows that the economic activity in the agricultural farms which have received investment support has significantly improved compared to the agricultural farms not receiving any support. In the context of increase, the greatest impact is on the changes to the total value of the produce (increase of $51 \%$ from the support recipients, and only $20 \%$ from the non-recipients), value of the long-term investments ( $51 \%$ and $21 \%$, respectfully), proportion of the products sold to the products produced ( $31 \%$ to $15 \%$ ), to the number of the groups of produced agricultural products ( $30 \%$ to $11 \%$ ).

A direction focused on creation of additional value added to the already existing products is considered as prospective. It includes both direct supply chains and processing of goods, thus even more increasing its sales price. At this stage, cooperation plays a major role, when the raw materials to the relevant farm (artisans) engaged in the processing are supplied by various farms.

Saving of the application of resources is usually related to the latest technologies. Significant investments in the small farms were not made during the previous period of Latvian Rural Development Programme. It means that investments in new technologies are required for raising efficiency. Lack of fixed assets during this time has become even more pronounced and significantly delays the operation of the farm. Since the resources of the farms in majority of cases are very limited, the investment support available to SF is very important in this regard. 


\section{Conclusions, proposals, recommendations}

1) A change of paradigm is taking place in the studies and on the policy level of Europe, recognizing that the importance of SMF in the formation of the rural space is broader that considered so far on the basis of narrow economic criteria. It is therefore important in the formation of further policy to take into consideration also a contribution of these farms in such areas as sustainable farming, reduction of poverty and facilitation of employment, formation of attractive rural landscape, as well as density of population of the rural areas and development of communities/ areas.

3) A proportion of the small farms in Latvia is one of the largest in the EU, and they play a great role in employment and formation of socio economic environment in the rural areas. They therefore need a special policy with a purpose to stimulate their development and conservation.

4) In order to increase income of the small farms, it is important to activate in them a production process, especially facilitating production of products with a high value added. Targeted investments are necessary for this purpose.

5) Since the area payments currently play the most important role in ensuring the income of the small farms, transfer to the more target-oriented investment support measures in case of SF must be well-considered and gradual, taking into account also the public benefit provided by small farms.

\section{Bibliography}

1. Agricultural and Rural Convention. (2010). A Communication from Civil Society to the European Union Institutions on the future Agricultural and Rural Policy. ARC-2020.

2. Ambrosio-Albala, M., Bastiaensen, J. (2010). The New Territorial Paradigm of Rural Development: Theoretical foundations from systems and institutional theories. Discussion Paper 02. Institute of Development Policy and Management. University of Antwerp.

3. Davidova, S., \& Thomson, K. (2013). Family Farming: a Europe and Central Asia Perspective. Background Report for Regional Dialogue on Family Farming: Working Towards a Strategic Approach to Promote Food Security and Nutrition.

4. De Castro, P., Adinolfi, F., \& Capitanio, F. (2014). Family Farming. Issues and Challenges in the Reformed Common Agriculture Policy. Economía Agraria y Recursos Naturales-Agricultural and Resource Economics, 14(1), pp. 169-176.

5. ESPON \& MCRIT LTD, (2014). Territorial Scenarios and Visions for Europe Final Report | 30/06/2014

6. European Parliament (2013). Report on the Future of Small Agricultural Holdings (2013/2096(INI)) Commission Committee on Agriculture and Rural Development.

7. Eurostat, (2013). Retrieved: http://ec.europa.eu/eurostat/data/database. Access: 12.11.2017.

8. FAO, (2014). The State of Food and Agriculture Innovation in family farming.

9. Gioia, A. (2017). Small Farms in Europe: Time for a Re-Definition. Ecoruralis

10. Ishii-Eiteman, M. Feeding the World, Greening the Planet. (2009). Summary of Findings of the International Assessment of Agriculture Knowledge, Science and Technology for Development. IAASTD Fact sheet. (IAASTD) https://www.globalonenessproject.org/sites/default/files/downloads/IAASTD \%20Fact \%20Sheet.pdf

11. Kern, M. (2015). Vision: Do More with Less, Better in Time! Sustainable Value Creation in Agriculture by Implementing Digital Technologies. In Computer Application Towards Agri-Biology and Engineering Streams. Eds: R. Hbehl at al. Agrobios Publishers, in press.

12. Meike, F. (2017). Small Farms in Europe: Viable but Underestimated. EcoRuralis, 9 p.

13. Molders, T. (2014). Multifunctional Agricultural Policies: Pathways towards Sustainable Rural Development? Int. Jrnl. of Soc. of Agr. \& Food, Vol. 21, No. 1, pp. 97-114.

14. Novikova, A. (2014). Valuation of Agricultural Externalities: Analysis of Alternative Methods. Research for Rural Development, Volume 2.

15. OECD, (2017). Summary Record Of The Nineteenth Meeting Of The OECD Network On Farm Level Analysis. Paris, 22-23 May, 1st session, (12).

16. Pollan, M. (2006). The Omnivore`s Dilemma: A Natural History of Four Meals. Newrk: Penguin Books.

17. Thompson, p. (2010). The Agrarian Vision: Sustainability and Environmental Ethics. Lexington: University Press of Kentucky. 
18. Tisenkopfs, T., Sumane, S, Kunda, I., Pilvere, I., Zeverte-Rivza, S., Stokmane, I. (2015). Latvijas mazo saimniecibu dzivotspeja (Viability of Latvian Small Farms). Baltijas Studiju Centrs un Latvijas Lauksaimniecibas universitate (Centre of Baltic Studies and Latvian Agricultural University).

19. Toward Sustainable Agricultural Systems in the 21st Century (2010). National Academy of Sciences. The National Academies Press. Washington.

20. Veveris, A., Sapolaite, V. (2017). Accessibility of Rural Development Programme Support for Small Rural Farms in Latvia. Economic Science for Rural Development No.44, Jelgava, pp. 345-352.

21. What is a small farm? (2011). European Commission. Agriculture and Rural development. EU Agricultural Economics Briefs. No2 - July 2011, pp. 11. 